\title{
抗 $\mathrm{M}$, 抗 $\mathrm{N}$ ノクローナル抗体の作製掞よび特異性の検討
}

勝野 誠 岡本 宏明 立花 克己 今井 光信
自治医科大学予防生態
池 本 卯 典
自治医科大学人間生物学

（昭和61年 7 月 15 日受付）

\section{MOUSE MONOCLONAL ANTIBODIES SPECIFIC FOR M AND N BLOOD GROUP-RELATED ANTIGENS}

\author{
Makoto Katsuno, Hiroaki Okamoto, Katsumi Tachibana, Mitsunobu Imai \\ and Shigenori Ikemoto* \\ Immunology Division, Jichi Medical School, Tochigi \\ *Laboratory of Human Biology, Jichi Medical School, Tochigi
}

\begin{abstract}
Eleven examples of mouse monoclonal antibodies were produced with specificities related to human blood group $\mathrm{MN}$ antigens. The eleven monoclonal antibodies, comprising eight which react with $\mathrm{M}$ antigen and three with $\mathrm{N}$ antigen, react in direct hemagglutination system, and their specificities were investigated by their reaction with panel and enzyme-modified red cells. The antibodies were used, in parallel with conventional polyclonal anti-M and anti-N sera, to type a series of random blood donors. The results obtained with the monoclonal antibodies and the polyclonal reagents were in perfect agreement. The monoclonal anti-M and anti-N antibodies could prove to be valuable alternatives to conventional reagents used currently for $\mathrm{MN}$-blood grouping.
\end{abstract}

\section{緒 言}

ヒトの MN 式血液型を判定する凝集反応用試 薬として，古くからポリクローナル抗 $\mathrm{M}$ ，抗 $\mathrm{N}$ 血 清が広く用いられている。一般に，ポリクローナ ル抗血清は，ウサギなどの動物を免疫して作製さ れているため，血液型判定用試薬として使用する 際には，ヒト赤血球に対する正常異種凝集素など を吸収操作により取り除く必要がある，それに対 して, 細胞融合法によって作製されるモノクロー ナル抗体は, 単一な抗原決定基を認識しているた め, 繁雑な吸収操作を必要とせず，常に均質な抗 体として安定して入手することができる。

Fraser らは抗Mモノクローナル抗体を作製す る目的で, MM 型七ト赤血球膜より抽出して得ら れたシアロ糖蛋白（グリコホリン）でマウスを免 疫したが，ほとんどすべてのヒト赤血球膜上に存 在するグリコホリン $\mathrm{B}$ の $\mathrm{N}$ 型抗原に対する免疫応 答として抗 $\mathrm{N}$ 抗体が得られ，抗 $\mathrm{M}$ 抗体は得られな
かったことを報告している1).著者らも，抗 $\mathrm{N}$ そ クローナル抗体は, $\mathrm{MN}$ 型ヒト赤血球を免疫原と

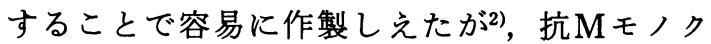
ローナル抗体の作製にあたっては，簢便かつ効率 よく株化でさるように，免疫方法を工夫して行っ た。すなわち， B, MM 型赤血球をトリプシン処理 し，上清中に遊離したグリコホリン $\mathrm{A}$ を初回免疫 に用い， A， MM 型の未処理赤血球を追加免疫に 用いることによって，選択的に多くの抗Mモノク ローナル抗体を作製できた。

以上の抗 $\mathrm{M}$ および抗 $N$ モクローナル抗体の特 異性を市販のポリクローナル抗 $\mathrm{M}$, 抗 $\mathrm{N}$ 血清と比 較，検討した結果，これらが有用なモノクローナ ル抗 $M$ ，抗N凝集素であると考えられたので報告 する。
材料と方法
1. モノクローナル抗体の作製
a) 抗Nモノクローナル抗体 
生理的食塩水で十分に洗浄した表現型 $\mathrm{B}, \mathrm{MN}$ のヒト成人赤血球 $\left(2 \times 10^{7}\right.$ cells $)$, 初回および 1 カ月後に BALB/c 雄マウス 1 匹の腹腔内に投与 した. 追加免疫としてさらに 1 カ月後に同量の B, MN 型赤血球を尾静脈内に投与した.

細胞融合は, Oi \& Herzenberg ${ }^{3)}$ 方法に従い, $50 \%$ ポリチレングルコール1500（和光純薬）を 用いて, 追加免疫の 3 日後に摘出した脾細胞とマ ウス骨䯣腫細胞（NS-1）とを細胞数比10：1で融 合した。15\%ウシ血清と HAT (hypoxanthine, aminopterine, thymidine）を含むRPMI-1640培 地で 9 日間培養の後, 免疫に用いた赤血球に対し て凝集活性を有するハイブリドーマを選択した。

限界希釈法によりクローン化し，抗N抗体を産 生するクローンについては, あらかじめ $0.5 \mathrm{~m} l$ の プリスタンを投与した $\mathrm{BALB} / \mathrm{c}$ マウスの腹腔内 に $1 \times 10^{7}$ cells を移植し, 約 $1 \sim 2$ 週間後に貯留し た腹水を採取した。得られた腹水は，40\%飽和硫 酸アンモニウムで塩析し, 生理的食塩水で十分に 透析して以後の検討に使用した。

b) 抗Mモノクローナル抗体

生理的食塩水で十分に洗浄した表現型 $\mathrm{B}, \mathrm{MM}$ のヒト成人赤血球 (packed cells) $3 \mathrm{~m} l$ にトリプシ ン溶液 (Sigma, type XI) $3 \mathrm{~m} l$ を加光, $37^{\circ} \mathrm{C} て ゙ 30$ 分間加温した。トリプシン溶液は, トリプシンを $0.1 \mathrm{M}$ リン酸緩衝液 $(\mathrm{pH} 7.7)$ に $8 \mathrm{mg} / \mathrm{ml}$ となる よう溶解し, 使用した。 トリプシン処理赤血球の 浮遊液を $2,000 \mathrm{rpm}$ で 5 分間遠心し, 分離した上 清に, 残留トリプシンを不活化する目的で $\mathrm{BALB} / \mathrm{c}$ マウス IgG 1mgを加えた。約10倍に濃 縮した上記反応液を抗Mポリクローナル抗血清に 加え, トリプシン処理により遊離したグリコホリ ン $\mathrm{A} か ゙ \mathrm{MM}$ 型赤血球の凝集反応を阻止すること を確認した。グリコホリン $\mathrm{A}$ 濃縮液の $200 \mu l$ を等 量の Freund の完全アジュバントに混じ, BALB/ c 雄マウス 1 匹の腹腔内に投与した. 追加免疫と して, 1 力月後に表現型 $\mathrm{A}, \mathrm{MM}$ の ト成人赤血 球 $\left(4 \times 10^{8}\right.$ cells $)$ を尾静脈内に投与した.

細胞融合は, 抗 $\mathrm{N}$ ノクローナル抗体作製の場 合と同様に行った.

また，抗体のサブクラスとタイプは, Miles 社の
ウサギ抗マウスイムノグロブリン $\left(\mathrm{IgG}_{1}, \mathrm{IgG}_{2 a}\right.$, $\mathrm{IgG}_{2 \mathrm{~b}}, \mathrm{IgG}_{3}, \mathrm{IgM}, \mathrm{k}, \lambda$ ) パネル血清を用いた micro Ouchterlony 法によって判定した.

2. 酵素処理赤血球との反応性の検討

$\mathrm{MM}, \mathrm{MN}$ および NN 型赤血球をそれぞれトリ プシン, キモトリプシン (Sigma, type II), ノイ ラミニダーゼ(Sigma, type V), パパイン(Sigma, type IV)等の酵素で処理し，抗 $\mathrm{M}$ および抗 $\mathrm{N}$ ) クローナル抗体との反応性を, 市販の抗 $\mathrm{M}$ 和よび 抗Nポリクローナル抗血清 (Ortho; MM513A, NN613A）と比較, 検討した.

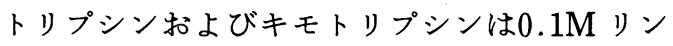
酸緩衝液 $(\mathrm{pH} 7.7)$ に, パパインは $0.1 \mathrm{M}$ リン酸 緩衝液 $(\mathrm{pH} 7.2)$ にそれぞれ $1 \mathrm{mg} / \mathrm{m} l$ の濃度とな るよらに溶解し, ノイラミニダーゼは $1 \mathrm{U} / \mathrm{m} l$ とな るように生理的食塩水に溶解して使用した。 それ ぞれ，生理的食塩水で十分に洗浄した赤血球 (packed cells) にその 5 倍量を加光, $37^{\circ} \mathrm{C} て ゙ 1$ 時 間加温振盪した。酵素処理後の赤血球は, 生理的 食塩水で十分に洗浄し，3\%濃度となるように生 理的食塩水に浮遊し, 以後の赤血球凝集反応に供 した.

凝集反応はすべて試験管を用い，室温で10分間 感作した後 $1,000 \mathrm{rpm}$ で 1 分間遠心し, 肉眼的に 観察して凝集の有無を判定した。なお，ポリクロー ナル抗血清およびモノクローナル抗体は, ともに 抗体価を 2 倍から 4 倍に調製し, 凝集反応に使用 した。

\section{結 果}

1. モノクローナル抗体の作製

a) 抗 $\mathrm{N}$ モノクロール抗体

免疫抗原として用いた $\mathrm{B}, \mathrm{MN}$ 型赤血球に対し て凝集活性を示した79株(27.4\%)のハイブリドー マのらち， 3 株（No. 5354, 5355, 5358）を抗N抗 体産生株として選択した（表 1）。

b) 抗Mモノクローナル抗体

追加免疫に用いた A, MM 型赤血球を凝集する 抗体は, 960wells の培養液中 315 wells（32.8\%に 認められた。そのうち $\mathrm{A}, \mathrm{NN}$ 型赤血球と反応せ ず， $\mathrm{A}, \mathrm{MM}$ 型赤血球とのみ凝集反応を示す抗体 は, 160wells に認められたが, クローニング後, 
表 1 抗M扣よび抗 $N$ モクローナル抗体

\begin{tabular}{|c|c|c|c|c|c|}
\hline \multirow{3}{*}{\multicolumn{2}{|c|}{$\begin{array}{c}\text { モノクローナル } \\
\text { 抗体 (No.) }\end{array}$}} & \multirow{3}{*}{ サブクラス/タイプ } & \multirow{2}{*}{\multicolumn{3}{|c|}{$\frac{\text { 抗体価（腹水 } 10 \mathrm{mg} / \mathrm{m} l \text { ) }}{\text { ヒト赤血球 }}$}} \\
\hline & & & & & \\
\hline & & & MM 型 & $\mathrm{MN}$ 型 & $\mathrm{NN}$ 型 \\
\hline \multirow{8}{*}{ 抗M } & 8017 & $\operatorname{IgG}_{1} / \mathrm{k}$ & $\times 6400$ & $\times 6400$ & $\leq \times 2$ \\
\hline & 8052 & $\operatorname{IgG}_{1} / \mathrm{k}$ & $\times 3200$ & $\times 3200$ & $\leq \times 2$ \\
\hline & 8006 & $\operatorname{IgG}_{1} / \mathrm{k}$ & $\times 1600$ & $\times 1600$ & $\leq \times 2$ \\
\hline & 8082 & $\mathrm{IgG}_{1} / \mathrm{k}$ & $\times 1600$ & $\times 1600$ & $\leq \times 2$ \\
\hline & 8088 & $\operatorname{IgG}_{2 b} / k$ & $\times 1600$ & $\times 1600$ & $\leq \times 2$ \\
\hline & 8001 & $\mathrm{IgG}_{3} / \mathrm{k}$ & $\times 800$ & $\times 800$ & $\leq \times 2$ \\
\hline & 8010 & $\mathrm{IgG}_{3} / \mathrm{k}$ & $\times 800$ & $\times 800$ & $\leq \times 2$ \\
\hline & 8070 & $\mathrm{IgG}_{3} / \mathrm{k}$ & $\times 800$ & $\times 800$ & $\leq \times 2$ \\
\hline \multirow{3}{*}{ 抗 $N$} & 5354 & $\operatorname{IgG}_{1} / \mathrm{k}$ & $\times 640$ & $\times 5120$ & $\times 5120$ \\
\hline & 5355 & $\operatorname{IgG}_{2 \mathrm{a}} / \mathrm{k}$ & $\times \quad 40$ & $\times 640$ & $\times 640$ \\
\hline & 5358 & $\operatorname{IgG}_{1} / \mathrm{k}$ & $\times 20$ & $\times 160$ & $\times 320$ \\
\hline
\end{tabular}

$\mathrm{MM}, \mathrm{MN}$ 型赤血球との凝集力価が高く, $10 \mathrm{mg} /$ $\mathrm{m} l$ の高い抗体濃度でも $\mathrm{NN}$ 型赤血球とはほとん ぞ反応しない抗Mモノクローナル抗体産生株を 8 株 (No. 8001, 8006, 8010, 8017, 8052, 8070, 8082, 8088）選択した（表 1 ）。

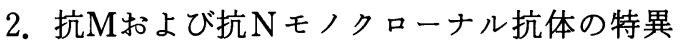
性の検討

精製した腹水の抗体価を 2 ないし 4 倍に調整 し，パネル血球（Ortho； Lot RA 354）を用いて 抗体比較同定試験を行った。 その結果, 表 1 に示 した 8000 番台の 8 株のモノクローナル抗体はいず れも抗M凝集素としての，また，5300番台の 3 株 のモノクローナル抗体は，抗N凝集素としての特 異性を有していることが確認された。 そこで，凝 集素活性が一番高く, $10 \mathrm{mg} / \mathrm{m} l$ の抗体濃度で

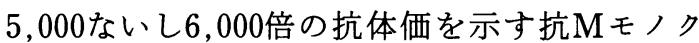
ローナル抗体（No. 8017）と抗Nモノクローナル 抗体（No. 5354）を選び，抗体価を 2 ないし 4 倍
に合わせて，以下の検討を行った。

ヒト成人赤血球 263 例を対象として,市販のポリ クローナル抗血清による $\mathrm{MN}$ 式血液型判定結果 との比較を行った. 抗 Mモノクローナル抗体(No. 8017)は, MM 型85例, $\mathrm{MN}$ 型139例の赤血球を凝 集したが，39例の $\mathrm{NN}$ 型赤血球を凝集しなかっ た。また，抗Nモノクローナル抗体 (No. 5354) は, MN 型139例, $\mathrm{NN}$ 型39例の赤血球を凝集した が, 85例の MM 型赤血球を凝集しなかった。この

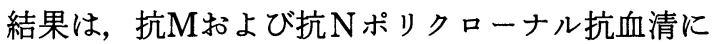
よる判定結果と完全に一致した（表 2 ）.

3. 酵素処理赤血球との反応性の検討

抗Mモノクローナル抗体执よび抗Mポリクロー ナル抗血清と, トリプシン処理 MM ないし MN 型赤血球との反応性は, 酵素処理前と比較し低下 した。抗Nモノクローナル抗体和よび抗Nポリク ローナル抗血清と, トリプシン処理赤血球との反 応性は上昇し, MM 型赤血球でも凝集反応が認め られた。 キモトリプシン処理赤血球と, 抗 $M$, 抗

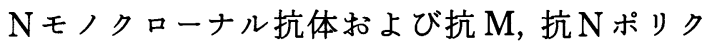
ローナル抗血清との反応性は酵素処理前後で著変 は認められなかった。一方，パパインで処理した 赤血球と，抗 $M$, 抗 $N$ 抗体との反応性はモノク ローナル抗体とポリクローナル抗血清とで一致し

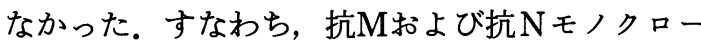
ナル抗体とパパイン処理赤血球との反応性は低下 したが，ポリクローナル抗血清ではその反応性の 低下は認められず，抗Mポリクローナル抗血清は $\mathrm{MM}, \mathrm{MN}$ 型のみならず $\mathrm{NN}$ 型赤血球を，抗 $\mathrm{N} ホ ゚$ リクローナル抗血清は $\mathrm{NN}, \mathrm{MN}$ 型のみならず MM 型赤血球をも凝集した。 また，ノイラミニ

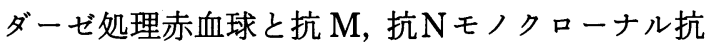

表 2 抗 $\mathrm{M}$, 抗 $\mathrm{N}$ モクローナル抗体による赤血球凝集反応 一抗M，抗Nポリクローナル抗血清との比較一

\begin{tabular}{c|c|c|c}
\hline${ }^{*} \mathrm{MN}$ 表現型 & $\begin{array}{c}\text { ヒト赤血球 } \\
\text { 検体数 }\end{array}$ & $\begin{array}{c}\text { 抗Mモノクローナル抗体 } \\
\text { (No.8017)により } \\
\text { 凝集した検体数 }\end{array}$ & $\begin{array}{c}\text { 抗Nモノクローナル抗体 } \\
\text { (No. 5354)により } \\
\text { 凝集した検体数 }\end{array}$ \\
\hline $\mathrm{MM}$ & 85 & $85(100 \%)$ & $0(0 \%)$ \\
$\mathrm{MN}$ & 139 & $139(100 \%)$ & $139(100 \%)$ \\
$\mathrm{NN}$ & 39 & $0(0 \%)$ & $39(100 \%)$ \\
\hline
\end{tabular}

*: 市販の抗Mポリクローナル抗血清 (Ortho; MM513A)抗Nポリクローナル抗血清 (Ortho；NN613A)を用いて判定した 
表 3 モノクローナル执よびポリクローナル抗 $\mathrm{M}$, 抗 $\mathrm{N}$ 凝集素と蛋白分解酵

素処理ヒト赤血球との反応性

\begin{tabular}{|c|c|c|c|c|c|}
\hline \multirow{2}{*}{$\begin{array}{l}\text { MN } \\
\text { 表現型 }\end{array}$} & \multirow[b]{2}{*}{ 酵素処理 } & \multicolumn{2}{|c|}{ ポリクローナル } & \multicolumn{2}{|c|}{ モノクローナル } \\
\hline & & $\begin{array}{c}\text { 抗M } \\
\text { (Ortho) }\end{array}$ & $\begin{array}{c}\text { 抗N } \\
\text { (Ortho) }\end{array}$ & $\begin{array}{c}\text { 抗M } \\
\text { (No. 8017) }\end{array}$ & $\begin{array}{c}\text { 抗 } \mathrm{N} \\
\text { (No. } 5354)\end{array}$ \\
\hline $\mathrm{MM}$ & $\begin{array}{c}- \\
\text { トリプシン } \\
\text { キモトリプシン } \\
\text { パパイン } \\
\text { ノイラミニダーゼ }\end{array}$ & $\begin{array}{l}\text { m } \\
+ \\
m \\
m \\
m \\
+\end{array}$ & $\begin{array}{l}- \\
+ \\
- \\
+ \\
+^{w}\end{array}$ & $\begin{array}{l}\text { m } \\
- \\
\text { m } \\
- \\
-\end{array}$ & $\begin{array}{l}- \\
\text { m } \\
- \\
- \\
-\end{array}$ \\
\hline $\mathrm{MN}$ & $\begin{array}{c}- \\
\text { トリプシン } \\
\text { キモトリプシン } \\
\text { パパイン } \\
\text { ノイラミニダーゼ }\end{array}$ & $\begin{array}{l}\text { m } \\
+w \\
+ \\
+ \\
+\end{array}$ & $\begin{array}{l}\text { W } \\
+ \\
+ \\
\text { H } \\
+\end{array}$ & $\begin{array}{l}\text { m } \\
- \\
\text { m } \\
- \\
-\end{array}$ & $\begin{array}{l}\text { m } \\
\mathrm{W} \\
\mathrm{W} \\
- \\
-\end{array}$ \\
\hline $\mathrm{NN}$ & $\begin{array}{c}\text { - } \\
\text { トリプシン } \\
\text { キモトリプシン } \\
\text { パパイン } \\
\text { ノイラミニダーゼ }\end{array}$ & $\begin{array}{l}- \\
+w \\
- \\
+ \\
+\end{array}$ & $\begin{array}{l}\text { H } \\
+ \\
+ \\
\text { H } \\
H\end{array}$ & $\begin{array}{l}- \\
- \\
- \\
- \\
-\end{array}$ & $\begin{array}{l}\text { W } \\
\text { W } \\
\text { W } \\
- \\
-\end{array}$ \\
\hline
\end{tabular}

完全凝集を卅, 陰性をーで示し, 凝集反応を強い順に 4 段階 $\left(+\ldots,+H,+,+{ }^{w}\right)$ で表示

した。抗体は凝集価を 2 ないし 4 倍に調製して使用した

体との反応性は低下し, MN 式血液型にかかわら ず，いずれの赤血球でも凝集反応は認められな かった（表 3 ).

\section{考察}

Köhler と Milstein は，ヒッジ赤血球で免疫し たマウスの脾細胞とマウス骨髄腫細胞とを融合し て得たハイブリドーマが，抗ヒッジ赤血球凝集素 を産生分必しながら増殖し続けることを明らかに した4).これを契機として, 細胞融合の技術は飛躍 的な発展を遂げ，現在では免疫抗体作製の手法と してのみならず，その優れた特異性を利用して， 臨床医学上の診断や治療にも応用されている。 七 卜赤血球血液型抗原の $\mathrm{ABO}$ 式血液型や, $\mathrm{MN}$ 式 血液型に拈いても，それは例外ではない。

$M N$ 式血液型判定血清として，古くからヒト赤 血球でウサギなどを免疫して作製した抗血清が用 いられてきた。このポリクローナル抗血清は正常 異種凝集素などを含んでいるため，それらを吸収 除去しなければ，血液型判定用の特異的な抗体と して使用できず，その操作は極めて繁雑である。 それに対して細胞融合法によって作製されるモノ クローナル抗体では, その必要はなく, 特異性は
極めて高い.

Fraser らは1982年, 抗Mモノクローナル抗体を 作製することを目的とし，MM 型赤血球膜のグリ コホリン抽出物でマウスを免疫したが，グリコホ リン $\mathrm{B}$ の $\mathrm{N}$ 型抗原 $\left(\delta^{\mathrm{N}}\right)$ に対する免疫応答の結果,

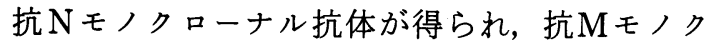
ローナル抗体は得られなかったことを報告し だ). その後, Bigbee ら ${ }^{5)}$, Nichols ら れ, $\mathrm{MM}$ 型ヒト赤血球由来の精製グリコホリン $\mathrm{A}, \mathrm{MM}$ 型ヒト赤血球を免疫原として，2株づつ 抗Mモノクローナル抗体を作製し, Fraser らも $\mathrm{MM}$ 型ヒト赤血球のグリコホリン分画および $\mathrm{MM}$ 型赤血球でマウスを免疫し， 4 株の抗Mモノ クローナル抗体を作製した ${ }^{7}$. 著者らは，抗 $\mathrm{N}$ ノ クローナル抗体については, MN 型の未処理赤血 球を免疫原とすることで 3 株作製することができ たが，その際，抗Mモノクローナル抗体は得られ

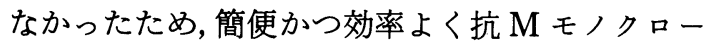
ナル抗体を作製できるように免疫方法を工夫して 行った.

ヒト赤血球の $\mathrm{M}$ 和よび $\mathrm{N}$ 型抗原は, 赤血球膜上 の 2 種類のシアロ糖蛋白（グリコホリンAおよび 
B)に存在することが知られている8).グリコホリ ンA（ $\alpha$ シアロ糖蛋白）は Tomita らによりペプ チドの全一次構造が決定され9)，1 分子中131個の アミノ酸を含み， $\mathrm{N}$ 末端より70個のアミノ酸残基 は, 細胞外に, C末端の約 40 個のアミノ酸残基は 細胞質内に存在し，糖鎖はすべて細胞外に局在し ていることが知られている。そのアミノ酸配列は $\mathrm{MN}$ 型に依存して異なる部分があり, MM 型赤血 球由来のものでは $\mathrm{N}$ 末端と 5 番目がセリンとグリ シンであり, $\mathrm{NN}$ 型赤血球由来のものでは, 口イ シンとグルタミン酸である。また，グリコホリン B ( $\delta$ シアロ糖蛋白) のアミノ酸配列は, $M N$ 式 血液型の表現型によらず， $\mathrm{N}$ 型赤血球由来のグリ コホリン $\mathrm{A} の \mathrm{~N}$ 末端から26番目までと全く同一で あるとされている、これらのM型およびN型抗原 活性は，種々の蛋白分解酵素の修飾をうけ，トリ プシン処理を行うと, $\mathrm{M}$ をた $\mathrm{N}$ 型抗原活性 $\left(\alpha^{\mathrm{M}}\right.$, $\alpha^{\mathrm{N}}$ )をもつペプチド鎖（30ないし40アミノ酸残基） がグリコホリンAから遊離し，グリコホリン $\mathrm{B} の$ $\mathrm{N}$ 型抗原活性 $\left(\delta^{\mathrm{N}}\right)$ は赤血球膜上にそのまま残る ことが知られている ${ }^{10)}$.

そこで，著者らは抗Mモノクローナル抗体の作 製にあたって， B， MM 型ヒト赤血球をトリプシ ン処理して上清中に遊離したグリコホリンAを初 回免疫に用い, 追加免疫には未処理の A, MM 型 赤血球を用いることで，極めて効率よく抗Mモノ クローナル抗体を作製することができた，凝集素 活性を有する抗体は960wells 中 315 wells （32.8\%）に認められ，そのらち51\%の抗体は A $\mathrm{NN}$ 型赤血球と反応せず， $\mathrm{A}, \mathrm{MM}$ 型赤血球のみ を凝集した。それらの抗体のなかには，濃度を高 くすることにより，NN 型赤血球と交叉反応性を 示すものも含まれていたが，上記の免疫方法に よって抗Mモノクローナル抗体として特異性に優 れた抗体を 8 株作製しえた。酵素処理赤血球との 反応性を検討すると，8株の抗Mモノクローナル 抗体はいずれも，ノイラミニダーゼ処理により， 凝集素活性が失われたことから，シアロ糖鎖を含 む抗原決定基を認識しているものと考えられる。 3 株の抗 $\mathrm{N}$ ノクローナル抗体も同様, ノイラミ ニダーゼ処理後，凝集反応を示さなくなったこと
より，それらの認識する抗原決定基にはシアロ糖 鎖が含まれるものと推測された。

著者らの抗 $\mathrm{N}$ ノクローナル抗体はいずれも， Fraser ら, Allen ら ${ }^{11)} の$ 作製した抗体と同様, 抗体 濃度を高くすることにより，MM 型赤血球をも凝 集した。この現象はキモトリプシン処理 MM 型赤 血球では消失することから，これらの抗体が，グ リコホリン $\mathrm{A} の \mathrm{~N}$ 型抗原 $\left(\alpha^{\mathrm{N}}\right)$ のみならず，殆ど 全てのヒト赤血球が共通にもつグリコホリン Bの $\mathrm{N}$ 型抗原 $\left(\delta^{N}\right)$ とも反応しらるためと考えられる.

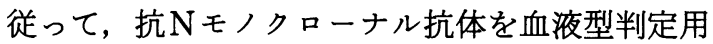
試薬として用いる場合には，抗Nポリクローナル 抗血清と同様, MM 型赤血球を凝集しないような 抗体価に調整する必要がある。

ポリクローナル抗血清では非特異凝集素を吸収 除去する必要があり，常に均質なものを得ること は容易ではない。また，ヒト赤血球をノイラミニ ダーゼあるいはパパインで処理することにより， ポリクローナル抗血清は, 酵素処理前には凝集し なかった赤血球を凝集するようになったことか ら，通常の血液型判定には問題とならない程度で はあるが，抗Mあるいは抗 $\mathrm{N}$ 抗体以外の非特異抗 体が少量混入しているものと思われる。それに対 して，抗 $\mathrm{M}$ おび抗 $\mathrm{N}$ モクローナル抗体では， 確立された抗体産生株より安定して入手でき，繁 雑な吸収操作を必要としない。また，イヌ，ウマ， ウシ，ブタ，ニワトリ，ガチョウなどの動物赤血 球とも交叉反応性を示さなかった。従って，今回 作製した抗Mおよび抗 $\mathrm{N}$ モクローナル抗体は， 特異性に優れ，血液型判定用試薬として有用であ ると同時に, MN 式血液型の抗原構造を免疫学的 に解明するらえでも，重要な役割を果たし得るも のと期待される。

\section{結 論}

細胞融合法により，MN 式血液型抗原に対する 抗体として抗Mマウスモノクローナル抗体を 8 株，抗Nマウスモノクローナル抗体を 3 株作製し た. いずれも IgGクラスの抗体であったが，凝集 反応にはクームス血清を必要とせず,精製腹水(抗 体蛋白濃度 $10 \mathrm{mg} / \mathrm{ml}$ ) で5,000ないし6,000倍の凝 集価を示す抗M (No. 8017)，抗N (No. 5354) 抗 
体が得られた。これらの抗体は特異性に優れ，常 に安定して入手可能であることから，MN 式血液 型判定用試薬として有用であると考えられた。

\section{文献}

1) Fraser, R.H., Munro, A.C., Williamson, A.R., Barrie, E.K., Hamilton, E.A. and Mitchell, R.: Mouse monoclonal anti-N. I. Production and serological characterization. J. Immunogenet., 9: 295-301, 1982.

2) 岡本宏明, 臼田定和, 立花克己, 田中栄司, 池本 卯典：モノクロナール抗 $\mathrm{N}$ 凝集素の作製および 特異性の検討. 医学々生物学, $110: 149-154$, 1985.

3) Oi, V.T. and Herzenberg, L.A.: Selected methods in cellular immunology. Freeman, W. H. \& Co, San Francisco, 1980, pp. 351-372.

4) Köhler, G. and Milstein, C.: Continuous cultures of fused cells secreting antibody of predefined specificity. Nature, 256: 495-497, 1975.

5) Bigbee, W.L., Vanderlaan, M., Fong, S.S.N. and Jensen, R.H.: Monoclonal antibodies specific for the $\mathrm{M}$-and $\mathrm{N}$-forms of human glycophorin A. Mol. Immunol., 20 : 1353-1362, 1983.
6) Nichols, M.E., Rosenfield, R.E. and Rubinstein, P.: Two blood group M epitopes disclosed by monoclonal antibodies. Vox. Sang., 49: 138 $-148,1985$.

7) Fraser, R.H., Inglis, G., Mackie, A., Munro, A. C., Allan, E.K., Mitchell, R., Sonnenborn, H.H. and Uthemann, H.: Mouse monoclonal antibodies reacting with $\mathrm{M}$ blood group-related antigens. Transfusion, 25: 261-266, 1985.

8) Furthmayr, H.: Structural comparison of glycophorines and immunochemical analysis of genetic variants. Nature, 271 : 519-524, 1978.

9) Tomita, M. an Marchesi, V.T.: Amino-acid sequence and oligosaccharide attachment sites of human erythrocyte glycophorin. Proc. Natl. Acad. Sci. U.S.A., 72 : 2964-2968, 1975.

10) Anstee, D.J. and Edwards, P.A.W.: Monoclonal antibodies to human erythrocytes. Eur. J. Immunol., 12 : 228-232, 1982.

11) Allen, R.W., Nunley, N., Kimmeth, M.E., Wallhermfechtel, M. and Vangelen-Tylor, V.: Isolation and serological characterization of a monoclonal antibody recognizing the $\mathrm{N}$ blood group antigen. Transfusion, 24 : 136-140, 1984. 